\title{
ON THE MARKET
} \section{DATABASES \\ Derwent's gene therapy database} draws together information from over 1,200 scientific journals, patents from 36 countries and worldwide conference proceedings onto one CD-ROM. The company says that the records go back to 1982 when the initial findings in the area of gene therapy were made. Subscribers to the database will each month receive a complete updated database containing 100-200 new abstracts. Each record provides bibliographic and abstracted information. Rapid search facilities are provided by the availability of four classification codes: therapeutic indication, gene transfer system/vector and gene manipulation technique. An additional classification section is set aside for legal and ethical issues. The annual subscription fee is $£ 650$; a 25 per cent discount is available for academic users. Derwent says that no previous knowledge is required due to intuitive search-and-retrieval software from Dataware Technologies (MS-DOS or Windows). Both sets of software are supplied on the same CD-ROM. An Apple Macintosh version will be available in early 1995 .

Reader Service No.150

Tel. (+44) 171-344-2800/

mmccolgan@derwent.co.uk

\section{VECTOR DESIGN}

Microbiological Associates offers viral vector production under Good Manufacturing Practice conditions, in addition to a range of validated assays.

Reader Service No. 151

Tel. (+44) (0)786-451318/

(+49) 561-32416

Q-One Biotech, a UK biotechnology company established in 1990, offers a comprehensive package of safety testing and production services for gene therapy. The company is fully accredited for Good Laboratory Practice (GL.P) and can provide a full range of testing services from master cell bank through to patient monitoring, including replication competent virus testing and all other tests necessary for the approval and completion of clinical trials. Q-One has also recently constructed a suite of laboratories, operating in compliance with Good Manufacturing Practice (GMP), for the pro-

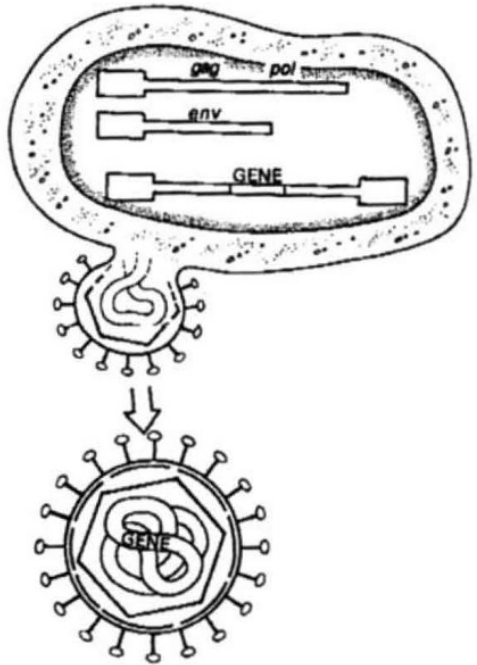

Packaging cell line containing a retroviral vector construct incorporating the therapeutic gene.

duction of vectors for gene therapy. The company says that production capabilities are soon to be expanded to a fully dedicated GMP facility to satisfy the demand for gene therapy products.

Reader Service No. 152

Tel. (+44) (0)141 946-9999

\section{ELECTROPORATION}

Two voltage ranges $(2.5 \mathrm{kV} / 500 \mathrm{~V})$, an additive capacitor bank, resistance timing and instantaneous monitoring - all within a single unit - are design features of the new ECM 600 electroporation system from BTX. Electroporation can be used to transfect or transform cells by rendering a membrane transiently permeable so that foreign genes, drugs or other large molecules can be introduced into the cell by means of pulsed electric fields. With the instrument, it is possible quickly to switch between electroporation of prokaryotic and eukaryotic cells. On the safety side, the

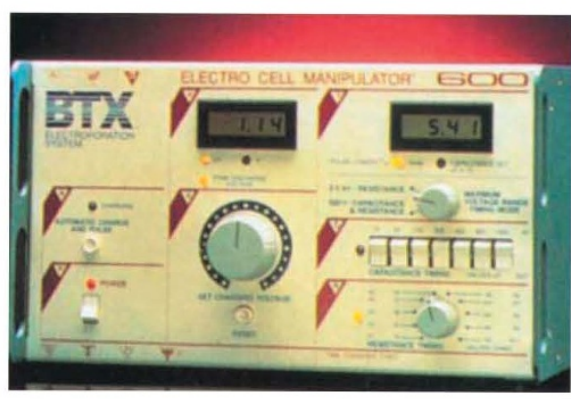

BTX's ECM 600 electroporation device offers users a choice of voltage ranges.
ECM 600 is designed to be shock-proof, arc-proof and short-circuit proof. The internal monitoring system measures true peak voltage and pulse length. Each system comes with a safety stand, cuvette rack and a pack of 50 sterile, disposable cuvettes in a choice of 1-, 2- or 4-mm gap sizes.

Reader Service No. 153

Tel. (+1) 619.597-6006/

1-800-289-2465

\section{TOOLS OF THE TRADE}

The Nest Group offers a low-cost method for the removal of endotoxins from nucleic acids. The $E^{2} B$ endotoxin extraction buffer is designed for use with the company's Nucleobond AX and other similar anion exchange, solid-phase extraction products. The treatment is used as an additional column wash buffer after the prescribed washes for a particular kit. When used with the Nucleobond AX system, Nest says that $E^{2} B$ has been shown repeatedly to reduce the level of endotoxins by more than 100 -fold to a level below $50 \mathrm{EU} \mathrm{ml}^{-1}$. DNA obtained from such preparations is said to be suitable for use in gene therapy applications, transgenic studies and for transfection into even sensitive cell lines.

Reader Service No. 154

Tel. (+1) 508-481-6223/

1-800-347-6378

Zeocin is a new antibiotic that is active in mammalian cells, fungi (including yeast), plants and bacteria. Invitrogen has incorporated the Zeocin resistance gene into its new mammallan expression vector, pZeoSV, so that the same drug can be used for selection in Escherichia coli as in mammalian cell lines. This new antibiotic is said to be more active than hygromycin B or G418. In addition, Invitrogen says that its effectiveness in bacteria allows the use of only one selectable marker in an expression vector. This is said to decrease vector size and increase ligation, transformation and transfection efficiency.

Reader Service No. 155

Tel. (+1) 619-597-6200/

1-800-955-6288

For more information, fill in the reader service card bound inside the journal. 